\title{
Pemanfaatan Citra Landsat 8 untuk Pemetaan Potensi Mineralisasi Emas di Kabupaten Tapanuli Selatan, Sumatera Utara
}

\author{
Shofitri Zuhannisa*, Bowo Eko Cahyono, Nurul Priyantari \\ Jurusan Fisika, Fakultas Matematika dan Ilmu Pengetahuan Alam, Universitas Jember, Jl. Kalimantan No.37, \\ Krajan Timur, Sumbersari, Kabupaten Jember, Jawa Timur 68121 \\ shofitrizuhannisa@gmail.com
}

\section{ABSTRACT}

The district of South Tapanuli is geologically an old volcanic area and is accompanied by a fault which indicates the presence of hydrothermally altered rocks which can be one indicator of the potential presence of one of the metals in gold. Geologically, gold is a metallic mineral that is closely related to the magmatic process and its formation environment within volcanic rocks. Current gold exploration activities are mostly carried out by field mapping methods, but these methods have constraints which require relatively high costs, energy, and time. Therefore, a method is needed to facilitate gold exploration, one of them is remote sensing. The purpose of this study was to map and measure the potential area of gold mineralization in South Tapanuli Regency by knowing the hydrothermal alteration zone by using the band ratios methods and lineament in the study location. The results of this study obtained the potential of gold minerals scattered in seven sub-districts, namely in Batang Toru District, Angkola Sangkunur, Sipirok, Angkola Timur, Aekbilah, Batang Angkola, and Sayurmatinggi. Measuring the area of potential for gold mineralization is carried out by making a polygon area. Based on the total area in each sub-district, it was concluded that the most potential gold mineralization in the South Tapanuli Regency was in Batang Toru District, which was also indicated by the existence of official gold mining activities operating in the Batang Toru region.

Keywords : Gold Mineralization, band ratios, alteration, lineament, South Tapanuli

\section{ABSTRAK}

Kabupaten Tapanuli Selatan secara geologi merupakan daerah vulkanik tua dan disertai dengan adanya sesar yang mengindikasikan adanya batuan teralterasi hidrotermal yang dapat menjadi salah satu indikator potensi keberadaan logam salah satunya emas. Secara geologi, emas merupakan mineral logam yang berkaitan erat dengan proses magmatik dan lingkungan pembentukannya berada di dalam batuan vulkanik. Kegiatan eksplorasi emas saat ini banyak dilakukan dengan metode pemetaan lapang, akan tetapi metode tersebut mempunyai kendala dimana memerlukan biaya, energi, dan waktu yang relatif tinggi. Oleh karena itu, diperlukan metode untuk memudahkan eksplorasi emas salah satunya dengan penginderaan jauh. Tujuan dari penelitian ini adalah melakukan pemetaan serta pengukuran luasan potensi mineralisasi emas di Kabupaten Tapanuli Selatan dengan cara mengetahui zona alterasi hidrotermal dengan menggunakan metode penisbahan saluran (band ratios) dan lineament (kelurusan) yang ada di lokasi penelitian. Hasil penelitian ini diperoleh potensi mineralisai emas tersebar di tujuh kecamatan, yakni di Kecamatan Batang Toru, Angkola Sangkunur, Sipirok, Angkola Timur, Aekbilah, Batang Angkola, dan Sayurmatinggi. Pengukuran luasan wilayah potensi mineralisasi emas dilakukan dengan membuat polygon area. Berdasarkan luasan total di setiap kecamatannya, diperoleh kesimpulan bahwa potensi mineralisasi emas di Kabupaten Tapanuli Selatan yang paling luas terdapat di Kecamatan Batang Toru, yang juga ditunjukkan dengan adanya aktivitas pertambangan emas resmi yang beroperasi di wilayah Batang Toru.

Kata Kunci : Mineralisasi emas, band ratios, alterasi, lineament, tapanuli selatan 


\section{PENDAHULUAN}

Pulau Sumatera merupakan salah satu pusat tambang emas tertua di Nusantara. Jalur emas sumatera berhimpitan dengan garis patahan karena adanya peristiwa geologi, sehingga sepanjang bukit barisan di Pulau Sumatera memiliki potensi emas yang melimpah. Sebagaian besar emas epitermal terakumulasi pada daerah busur magmatik. Salah satu daerah yang terdapat pada jajaran busur magmatik adalah Kabupaten Tapanuli Selatan, Sumatera Utara ${ }^{[1]}$. Kabupaten Tapanuli Selatan secara geologi merupakan daerah vulkanik tua dan disertai dengan adanya sesar yang mengidentifikasikan adanya batuan teralterasi hidrotermal. Adanya batuan teralterasi hidrotermal dapat menjadi salah satu indikator potensi keberadaan mineral logam salah satunya emas ${ }^{[2]}$.

Emas merupakan mineral logam yang berkaitan erat dengan proses magmatik. Lingkungan pembentukannya yang berada di dalam batuan vulkanik (vocanic heasted rocks) sering ditemukan di berbagai endapan. Endapan emas dalam batuan vulkanik pada umumnya terdapat dalam bentuk urat-urat tipis sebagai penyusupan larutan air panas (hydrotermal) yang mengandung mineral ke celah-celah, kemudian karena proses pendinginan, terjadi pengendapan di celah tersebut. Batuan vulkanik yang menjadi tempat dari endapan tersebut biasanya terdiri dari breksi kemudian berinteraksi dengan lava, sehingga menghasilkan intrusi. Intrusi ini menyebabkan terbentuknya retakan/celah-celah di sekitar zona intrusi ${ }^{\text {[3] }}$. Secara ekonomis emas merupakan bahan galian tambang yang banyak dinikmati oleh masyarakat. Mayoritas keberadaan emas saat ini dimanfaatkan sebagai perhiasan, bahan kosmetik, campuran mata uang, dan media investasi. Keberadaan emas sangat berharga, akan tetapi ketersediaannya di alam relatif sedikit. Oleh karena itu, teknologi dalam proses penambangan emas terus dikembangkan agar eksplorasi emas dapat lebih efektif dan efisien ${ }^{[1]}$.

Kegiatan eksplorasi tambang khususnya tambang emas saat ini banyak dilakukan dengan metode pemetaan geologi, parit uji, dan metode geokimia tanah/endapan sungai yang dimaksudkan untuk mengetahui kondisi geologi lokal, melokalisir penyebaran dan menafsirkan model/tipe pembentukan emas di wilayah kajian ${ }^{[4]}$. Eksplorasi yang dilakukan tersebut mempunyai kendala yaitu pada tahap pemetaan lapangan memerlukan biaya, energi, dan waktu yang relatif tinggi ${ }^{[1]}$. Melihat kendala tersebut, saat ini terus dikembangkan metode untuk memudahkan ekplorasi emas termasuk teknologi penginderaan jauh. Penginderaan jauh (remote sensing) merupakan ilmu atau seni untuk mendapatkan informasi tentang suatu obyek, daerah, atau fenomena melalui analisis data yang diperoleh dengan suatu alat tanpa kontak langsung dengan obyek, daerah, atau fenomena yang dikaji ${ }^{[5]}$. Teknologi penginderaan jauh atau yang juga disebut dengan inderaja, kini semakin berkembang melalui kehadiran berbagai satelit dengan berbagai misi dan teknologi sensor. Aplikasi satelit penginderaan jauh telah mampu memberikan data/informasi tentang sumberdaya alam daratan dan sumberdaya alam kelautan secara teratur dan periodik ${ }^{[6]}$.

Teknologi penginderaan jauh yang digunakan untuk memetakan potensi mineralisasi emas tidak lepas dari pemahaman mengenai kondisi geologi daerah kajian. Selain itu, struktur geologi yang juga menjadi pertimbangan dalam penentuan lokasi mineralisasi emas adalah lineament (kelurusan) dan patahan/sesar. Pola-pola lineament yang ada dapat menunjukkan adanya zona alterasi. Pada zona alterasi inilah terjadi perubahan komposisi mineral batuan. Perubahan komposisi mineral dapat terjadi dari proses kimia maupun dari pengaruh proses magmatisme. Pada zona alterasi umumnya terdapat potensi mineralisasi emas, terutama yang 
terletak pada daerah patahan dan batuan terobosan ${ }^{[3]}$. Lineament terutama patahan menjadi faktor dominan dalam pembentukan emas karena patahan merupakan jalur mengalirnya fluida hidrotermal ke permukaan. Faktor geologi lain yang juga mempunyai kontrol penting dalam kaitannya dengan mineralisasi emas adalah litologi (batuan). Litologi menjadi penting karena fluida hidrotermal yang naik ke permukaan akan memilih zona-zona litologi yang cenderung lemah sehingga relatif mudah ditembus ${ }^{[2]}$.

Penelitian sebelumnya membahas mengenai pemetaan potensi mineralisasi emas menggunakan teknologi penginderaan jauh ${ }^{[3]}$. Mereka melakukan pemetaan potensi mineralisasi emas di kawasan Gunung Dodo, Kabupaten Sumbawa, Nusa Tenggara Barat dengan menggunakan citra Landsat 7 ETM+. Metode penginderaan jauh yang diterapkan dalam penelitian tersebut yaitu metode penisbahan saluran (band ratios) yang digunakan untuk mengetahui zona alterasi. Hasil penelitian tersebut menunjukkan bahwa pengolahan citra digital dan interpretasi visual pada citra Landsat 7 ETM+ cukup baik untuk memperoleh data geologi, zona alterasi, kelurusan (lineament) dan geomorfologi. Namun, penelitian tersebut masih menggunakan citra Landsat 7 ETM+ yang hanya memiliki 8 band, dimana saat ini telah ada citra Landsat generasi terbaru yakni Landsat 8 yang memiliki 11 band, sehingga kualiatas citra semakin bagus.

Penelitian lain mengenai pemetaan potensi mineralisasi emas juga telah dilakukan oleh beberapa orang. Penelitian mengenai sebaran potensi emas epitermal di Cibalung, Pandeglang, Banten ${ }^{[2]}$. Citra yang digunakan dalam penelitian tersebut yaitu citra ASTER. Metode yang digunakan dalam penelitian tersebut yaitu metode band ratios dan Direct Principal Component Analysis (DPCA) untuk memetakan zona alterasi, serta Weights of Evidence untuk melihat asosiasi spasial antara emas epitermal dengan litologi dan struktur geologi (patahan). Hasil penelitian tersebut menunjukkan bahwa ketiga lokasi potensi emas epitermal yang telah terpetakan berada di dalam dan di luar area Kuasa Pertambangan (KP) eksploitasi.

Penelitian lain yaitu mengenai pemetaan potensi keberadaan emas epitermal dengan memanfaatkan data citra Landsat 8 OLI dan SRTM 30 meter di sebagian Kabupaten Tapanuli Selatan, Sumatera Utara ${ }^{[1]}$. Metode yang digunakan dalam penelitian tersebut yaitu menggunakan metode fuzzy logic dimana zona alterasi, struktur geologi, batuan (litologi), dan bentuk lahan digunakan sebagai input datanya. Penggunaan metode fuzzy logic mampu memberikan informasi potensi keberadaan emas epitermal dengan tingkat keakuratan dari model zonasi alterasi hidrotermal yaitu sebesar 80 persen. Kelemahan dalam penelitian Harahap dan Danoedoro ini yakni tidak mampu menghasilkan zona alterasi secara langsung, karena zona alterasi dalam penelitian tersebut diketahui berdasarkan interpretasi visual melalui analisis pendekatan litologi, bentuk lahan, dan struktur geologi. Selain itu, Harahap dan Danoedoro hanya memetakan potensi mineralisasi emas hanya di sebagian Kabupaten Tapanuli Selatan saja, tidak mencakup seluruh wilayah Kabupaten Tapanuli Selatan.

Pada penelitian ini, penulis melakukan pemetaan terhadap potensi mineralisasi emas di Kabupaten Tapanuli Selatan, Sumatera Utara dengan melihat adanya alterasi hidrotermal dan lineament (kelurusan) di lokasi penelitian. Alterasi hidrotermal dalam penelitian ini dapat diketahui keberadaannya dengan menggunakan metode penisbahan saluran (band ratios). Metode penisbahan saluran (band ratios) dapat digunakan secara langsung dalam memperoleh zona alterasi hidrotermal. Mengacu pada penelitian yang pernah dilakukan oleh Putra, dkk. 
(2017) ${ }^{[7]}$, zona alterasi hidrotermal yang diperoleh dari proses band ratios didasarkan pada rona/warna yang terlihat pada citra hasil pengolahan. Data citra satelit yang digunakan adalah citra Landsat 8. Citra Landsat 8 digunakan untuk mengekstrak informasi mengenai zona alterasi dan lineament (kelurusan) dengan berbagai pengolahan citra digital.

\section{METODE}

Pemetaan potensi mineralisasi emas dipetakan berdasarkan data berupa peta lineament (kelurusan) dan peta zona alterasi hidrotermal yang telah dilakukan penampalan (overlay). Identifikasi terhadap lokasi potensi mineralisasi emas ini dilakukan secara visual, dimana lokasi yang diidentifikasi sebagai potensi mineralisasi emas dilihat berdasarkan lineament yang terletak pada zona alterasi. Potensi mineralisasi emas setelah dipetakan juga perlu dilakukan identifikasi terhadap jenis batuan yang terdapat pada lokasi potensi mineralisasi emas. Hal tersebut dilakukan karena keberadaan mineral emas sangat tergantung dengan adanya suatu batuan tertentu. Identifikasi jenis batuan dilakukan dengan menggunakan peta geologi Lembar Padangsidempuan dan Sibolga. Selain identifikasi jenis batuan, dilakukan juga identifikasi terhadap tutupan lahan di daerah kajian yang dilakukan berdasarkan peta RBI regional Tapanuli Selatan, Sumatera Utara.

Potensi mineralisasi emas yang sudah terpetakan perlu diketahui seberapa luas wilayah yang berpotensi terdapat mineralisasi emas. Penghitungan luasan area potensi mineralisasi emas ini dilakukan dengan membuat polygon area, dimana luasan dari polygon ini dapat diketahui secara otomatis melalui software yang digunakan, pada penelitian ini menggunakan software Arcgis. Nantinya dari peta potensi mineralisasi emas yang dihasilkan akan dicocokkan dengan keberadaan daerah pertambangan emas resmi yang telah tereksploitasi di Tapanuli Selatan yaitu yang terletak di Kecamatan Batang Toru, sehingga dapat diketahui sejauh mana hasil interpretasi citra penginderaan jauh dengan keadaan sesungguhnya.

\section{HASIL DAN PEMBAHASAN}

\section{Alterasi Hidrotermal}

Keberadaan alterasi hidrotermal dapat menjadi petunjuk yang penting dalam melakukan pemetaan potensi mineralisasi emas. Alterasi hidrotermal dapat diketahui salah satunya dengan menggunakan metode band ratios. Alterasi hidrotermal keberadannya dapat diketahui dengan mengambil beberapa kombinasi saluran (band) dari data citra yang memiliki karakter reflektansi yang khas terhadap mineral-mineral alterasi hidrotermal. Penggunaan band-band tersebut mengacu pada penelitian yang telah dilakukan oleh Pour dan Hashim (2014). Pada beberapa band, dilakukan metode rasio (band ratios) yaitu metode membagi nilai Digital Number (DN) suatu band dengan nilai DN band yang lain untuk memperjelas kenampakan suatu objek di permukaan bumi yang sulit atau tidak dapat dilihat oleh band tunggal. 


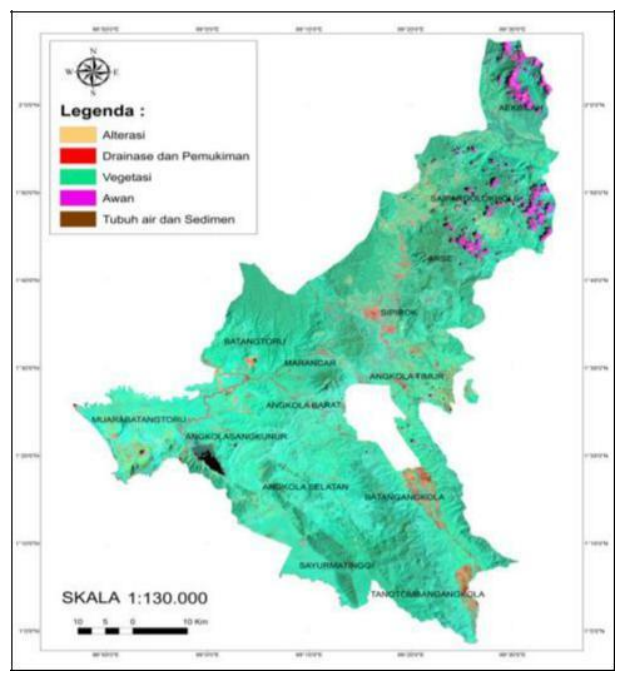

Gambar 1. Peta alterasi Kabupaten Tapanuli Selatan

Rasio yang dilakukan pada beberapa band yaitu band 4 dirasiokan dengan band 2 (rasio band 4/2), dan band 6 dirasiokan dengan band 7 (rasio band 6/7), untuk mendapatkan nilai pantulan yang semakin baik dari mineral alterasi hidrotermal di permukaan. Hasil dari rasio tersebut selanjutnya dikomposit RGB dengan band 5 (RGB band 4/2, 6/7, dan 5). Melalui citra komposit RGB 4/2, 6/7, dan 5, maka dapat diketahui penyebaran mineral alterasi hidrotermal (Gambar 1). Mineral alterasi hidrotermal dikenali dari kenampakan warna oranye kekuningan.

\section{Lineament}

Ekstraksi lineament dilakukan secara otomatis dengan menggunakan software PCI Geomatika. Hasil ekstraksi lineament tersebut kemudian digabungkan dengan lineament dari peta geologi yang sudah ada.

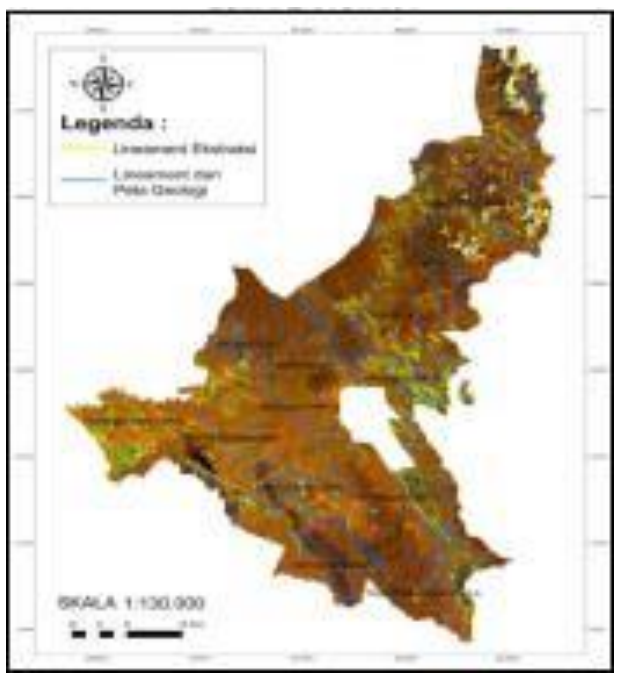

Gambar 2. Overlay lineament ekstraksi dengan lineament peta geologi 
Berdasarkan Gambar 2., dapat diketahui bahwa lineament hasil ekstraksi mempunyai jumlah yang lebih banyak dibandingkan dengan lineament dari peta geologi. Menurut Herlambang dan Novranza (2016), Jumlah lineament ekstraksi yang lebih banyak tersebut disebabkan geomorfologi daerah penelitian yang cenderung berbukit-bukit dan bertekstur kasar yang kemungkinannya dipengaruhi oleh jenis batuan pada formasi geologi, sehingga fitur kelurusan mudah untuk dideteksi dan diekstrak oleh metode ekstraksi otomatis. Selain itu, lineament hasil ekstraksi mempunyai ukuran yang berbeda dengan lineament dari peta geologi. Lineament dari peta geologi rata-rata berukuran mayor, sedangkan lineament yang didapat dari ekstraksi otomatis lebih merepresentasikan lineament dengan ukuran minor. Lineament yang berukuran mayor maupun yang berukuran minor tersebut jika terdapat di daerah yang mengalami alterasi, maka keduanya sama-sama mengindikasikan potensi mineralisasi emas.

\section{Pemetaan Potensi Mineralisasi Emas}

Menurut Sugeng (2005), keberadaan potensi mineralisasi emas sangat bergantung atas adanya alterasi hidrotermal dan kelurusan (lineament) yang saling berkaitan. Kelurusan dapat mengindikasikan keberadaan mineralisasi emas, dan alterasi sendiri juga merupakan faktor penting dalam identifikasi mineralisasi emas, dimana zona alterasi merupakan tempat terjadinya pembentukan mineral emas. Oleh karena itu, lineament dan alterasi perlu di overlay (tumpang-tindih).

Berdasarkan hasil overlay lineament dengan alterasi, maka dapat dilakukan pemetaan potensi mineralisasi emas dengan membuat polygon di area yang teridentifikasi sebagai potensi mineralisasi emas. Identifikasi daerah yang terdapat potensi mineralisasi emas dapat dilihat dari adanya lineament yang terletak di daerah yang mengalami alterasi. Berdasarkan lineament dan alterasi di daerah penelitian, maka didapatkan hasil pemetaan potensi mineralisasi emas yang dapat dilihat pada Gambar 3.

Berdasarkan hasil pemetaan yang telah dilakukan, potensi mineralisasi emas di Kabupaten Tapanuli Selatan dapat dilihat pada Gambar 3 (a). dimana didapatkan beberapa wilayah yang mengandung potensi mineralisasi emas yang tersebar di tujuh kecamatan, yakni di Kecamatan Batang Toru, Kecamatan Angkola Sangkunur, Kecamatan Sipirok, Kecamatan Angkola Timur, Kecamatan Aekbilah, Kecamatan Batang Angkola, dan Kecamatan Sayurmatinggi. Hasil pemetaan potensi mineralisasi emas yang didapatkan ini melengkapi hasil penelitian yang pernah dilakukan oleh Harahap dan Danoedoro (2016) serta data bahan tambang emas dari Badan Pusat Statistik (BPS) Kabupaten Tapanuli Selatan yang mempunyai data bahan tambang emas terdapat di Kecamatan Batang Toru, Batang Angkola, Sayur Matinggi, dan Aekbilah.

Potensi mineralisasi emas yang terdapat di wilayah Kecamatan Batang Toru Kabupaten Tapanuli Selatan, merupakan wilayah yang sudah di tambang, dimana di wilayah tersebut terdapat pertambangan emas resmi yang telah beroperasi. Lineament dan alterasi yang mengidentifikasikan potensi mineralisasi emas yang ada di wilayah Batang Toru tersebut ditunjukkan pada Gambar 3 (b). dimana wilayah potensi mineralisasi emas dibatasi dengan warna kuning, yakni suatu lineament yang terletak di zona alterasi. Sehingga, dapat dipetakan juga daerah lain dengan lineament yang terletak di zona alterasi seperti di wilayah Batang Toru atau yang mempunyai pola struktur yang sama bisa diperkirakan berpotensi mengandung mineralisasi emas. 


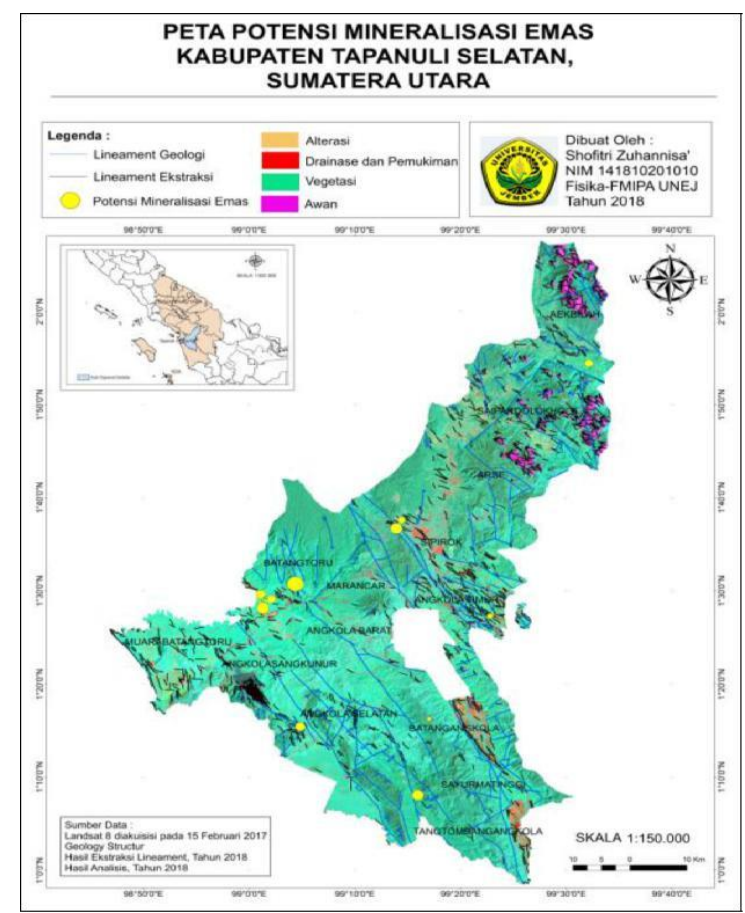

(a)

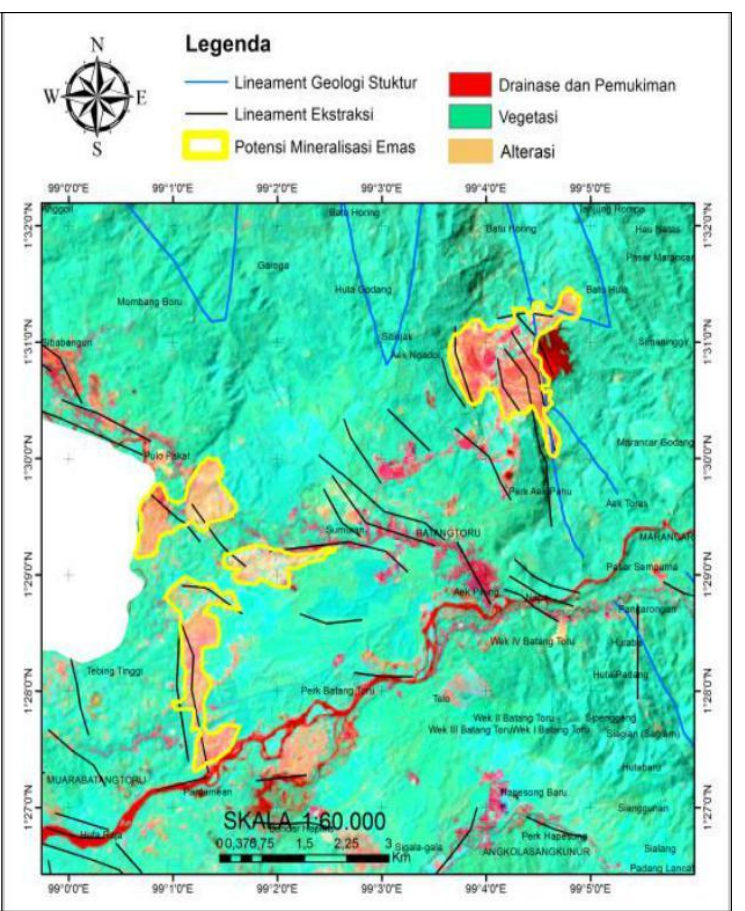

(b)

Gambar 3. Peta potensi mineralisasi emas (a) di Kabupaten Tapanuli Selatan, (b) di Kecamatan Batang Toru

\section{Sebaran Luasan Potensi Mineralisasi Emas}

Berdasarkan pemetaan potensi mineralisasi emas yang telah dilakukan, perlu diketahui luasan wilayah-wilayah yang terdapat potensi mineralisasi emas. Penghitungan luasan ini dilakukan dengan menggunakan polygon area yang telah dibuat pada Gambar 3. (diperlihatkan dengan warna kuning). Penghitungan luasan pada polygon area ini didapatkan secara otomatis yang dapat dilihat langsung melalui software yang digunakan. Potensi mineralisasi emas ini dihitung luasan total di setiap kecamatan, dapat dilihat pada Tabel 1.

Tabel 1. Luasan potensi mineralisasi emas di Kabupaten Tapanuli Selatan

\begin{tabular}{clc}
\hline No. & \multicolumn{1}{c}{ Kecamatan } & Luas total $\left(\mathbf{k m}^{\mathbf{2}}\right)$ \\
\hline 1. & Batang Toru & 6,0994 \\
2. & Angkola Sangkunur & 0,2718 \\
3. & Sipirok & 0,6952 \\
4. & Angkola Timur & 0,0704 \\
5. & Aekbilah & 0,3252 \\
6. & Batang Angkola & 0,0333 \\
7. & Sayurmatinggi & 0,1413 \\
\hline
\end{tabular}


Berdasarkan Tabel 1. tersebut, dapat disimpulkan bahwa lokasi potensi mineralisasi emas yang terbesar atau terluas adalah di Kecamatan Batang Toru yaitu dengan luas total $6,0994 \mathrm{~km}^{2}$. Namun, luas lokasi potensi mineralisasi emas di Batang Toru tersebut bukanlah satu titik lokasi saja, tetapi gabungan dari beberapa titik lokasi di satu kecamatan. Keberadaan potensi mineralisasi emas yang besar di Kecamatan Batang Toru tersebut juga ditunjukkan dengan adanya aktivitas pertambangan emas resmi yang beroperasi di wilayah Batang Toru.

\section{KESIMPULAN}

Kesimpulan yang diperoleh berdasarkan hasil pengolahan dan analisis data penelitian pemetaan potensi mineralisasi emas di Kabupaten Tapanuli Selatan, Sumatera Utara ini adalah pemetaan potensi mineralisasi emas dilakukan dengan overlay alterasi (yang dihasilkan dari metode band ratios) dan lineament. Pemetaan potensi mineralisasi emas dilihat berdasarkan suatu lineament yang terletak di zona alterasi. Berdasarkan hasil pemetaan yang telah dilakukan, potensi mineralisasi emas di Kabupaten Tapanuli Selatan tersebar di tujuh kecamatan. Lokasi terdapatnya potensi mineralisasi emas mempunyai luasan yang berbedabeda di tiap kecamatannya, dimana lokasi dengan potensi mineralisasi emas yang terbesar adalah di Kecamatan Batang Toru dengan luas total $6,1 \mathrm{~km}^{2}$. Sedangkan untuk luasan yang terkecil atau paling sedikit potensi mineralisasi emasnya adalah di Kecamatan Batang Angkola dengan luas $\left(3,3 \times 10^{-2}\right) \mathrm{km}^{2}$.

\section{DAFTAR PUSTAKA}

1 Harahap, R. S. R. \& Danoedoro, P. 2017. Aplikasi Penginderaan Jauh untuk Pemetaan Zonasi Potensi Keberadaan Emas Epitermal Menggunakan Metode Fuzzy Logic di Sebagian Kabupaten Tapanuli Selatan, Sumatera Utara. Jurnal Bumi Indonesia, 6 (1), 1-9

2 Wiguna, S. 2012. Sebaran Potensi Deposit Emas Epitermal di Cibalung, PandeglangBanten. Skripsi, Universitas Indonesia.

3 Paraditya, R. \& Purwanto, T. H. 2012. Pemanfaatan citra Landsat 7 ETM+ untuk pemetaan potensi mineralisasi emas di Kawasan Gunung Dodo, Kabupaten Sumbawa, NTB. Jurnal Bumi Indonesia., 1 (3), 122-129

4 Tampubolon, A. 2006. Eksplorasi Emas di Kabupaten Kerinci Provinsi Jambi. Prosiding Pemaparan Hasil-Hasil Kegiatan Lapangan dan Non Lapangan Pusat Sumberdaya Geologi, 1-6

5 Lillesand, T. M. \& Kiefer, R. W. 1997. Penginderaan Jauh dan Interpretasi Citra. Yogyakarta: Gadjah Mada University Press.

6 Martono, D. N. 2008. Aplikasi Teknologi Penginderaan Jauh dan Uji Validasinya untuk Deteksi Penyebaran Lahan Sawah dan Penggunaan/Penutupan Lahan. Seminar Nasional Aplikasi Teknologi Informasi 2008 (SNATI 2008). Yogyakarta, 47-56

7 Putra, I. D., Nasution, R. A. F. \& Harijoko, A. 2017. Aplikasi Landsat 8 OLI/TIRS dalam Mengidentifikasi Alterasi Hidrotermal Skala Regional: Studi Kasus Daerah Rejang Lebong dan Sekitarnya, Provinsi Bengkulu. Proseding Seminar Nasional Kebumian Ke$10,1812-1826$ 